\author{
MAGDALENA MASZKIEWICZ \\ Uniwersytet Jagielloński \\ Wydział Filologiczny
}

\title{
BIZANCJUM JAKO IDEAŁ SKAZANY NA UNICESTWIENIE I SENSOTWÓRCZA MIŁOŚĆ W CYKLU POETYCKIM O DZIEŁACH MIŁOŚCI ALBO BIZANCJUM IVANA V. LALICIA
}

Celem niniejszego artykułu jest interpretacja dwóch wskazanych w tytule motywów, pojawiających się w cyklu poetyckim $O$ dziełach miłości albo Bizancjum ${ }^{1}$ serbskiego poety Ivana V. Lalicia ${ }^{2}$. Postrzeganie Bizancjum jako rzeczywistości, która osiągnąwszy doskonałość, ulega unicestwieniu oraz miłości jako kategorii sensotwórczej wpisuje się w spójną wizję obecną w całej twórczości tego autora. Zawarte tu rozważania są przyczynkiem do zrozumienia omawianego cyklu, a zarazem poezji Lalicia jako całości.

Ivan V. Lalić jest przez historyków literatury i krytyków literackich w Serbii uznany za jednego z najwybitniejszych poetów ubiegłego stulecia. Bibliografia prac dotyczących jego twórczości obejmuje dziesiątki artykułów, tomów zbiorowych i monografii. Część utworów z cyklu, któremu poświęcony jest niniejszy artykuł zaprezentowała polskim czytelnikom w 1977 roku Joanna Salamon - ich tłumaczka i autorka posłowia do polskiego wydania opatrzonego tytułem $O$ dziełach miłości albo Bizancjum. W jej wyborze znalazły się

\footnotetext{
${ }^{1}$ Tytuł oryginalny: O delima ljubavi ili Vizantija. Cykl ten powstał w latach 1967-1968, a ukazał się po raz pierwszy jako część tomu poetyckiego Lalicia pt. Izabrane i nove pesme (Beograd 1969). W niniejszym artykule wykorzystano wydanie: I.V. Lalić, Dela Ivana V. Lalića, prir. A. Jovanović, t. II: O delima ljubavi ili Vizantija, Beograd 1997.

${ }^{2}$ Ivan V. Lalić (1931-1996) - wybitny serbski poeta, eseista i tłumacz literatury pięknej. Debiutował wraz z grupą innych twórców, określanych w literaturze przedmiotu jako drugie pokolenie poetów powojennych (A. Jovanović, Poezija srpskog neosimbolizma, Beograd 1994), w latach 50. XX wieku - jego debiutancką książkę z 1955 roku pt. Bivši dečak poprzedził szereg publikacji na łamach czasopism. Poezja Lalicia jest przez badaczy najczęściej nazywana „neosymbolizmem” (ibidem) lub „postsymbolizmem” (Postsimbolistička poetika Ivana V. Lalića. Zbornik radova, ur. A. Jovanović, Beograd 2007). Istotną cechę dorobku literackiego tego twórcy stanowią także liczne odwołania do tradycji oraz stosowanie technik poetyckich opartych na reinterpretacji i rekontekstualizacji znanych motywów i symboli, co uznaje się za rezultat inspiracji myślą T.S. Eliota (por. m.in. J. Delić, Lalićev dijalog sa savremenom srpskom poezijom - ka eksplicitnoj poetici Ivana V. Lalića, [w:] Postsimbolisticka poetika..., op. cit., s. 20, 52-58). Zob. także omówienie twórczości poetyckiej Lalicia w posłowiu do polskiego wydania jego wierszy: I.V. Lalić, $O$ dziełach miłości albo Bizancjum, wybór, przekład i posłowie J. Salamon, Kraków 1977, s. 193-205.
} 
utwory z trzech tomów poetyckich: Vreme, vatre, vrtovi (Czas, ogień, ogrody - 1961), Izabrane i nove pesme (Wiersze wybrane i nowe - 1969), z którego pochodzi omawiany w prezentowanym artykule cykl, oraz Smetnje na vezama (Zakłócenia łączności - 1975).

\section{„Wbrew wszystkiemu co straszne...”}

Rozważania należy zacząć od przedstawienia ważnego zadania, jakie według Lalicia stoi przed poetą dokonującym aktu twórczego. Jest nim afirmowanie zastanej rzeczywistości, mimo iż przynosi ona człowiekowi cierpienie, niepewność i śmierć. Na ten wątek zwróciło uwagę kilkoro badaczy. Między innymi Svetlana Šeatović-Dimitrijević, badając symbolikę morza w twórczości poety, zaznacza:

Za pomocą oksymoronu „dobroć okrutnego morza” Lalić tworzy obraz poetycki opisujący dwoistość morza, jego fatalną i sprzeczną moc. „Dobroć okrutnego morza” to twór oksymoroniczny, będący elementem ogólnej charakterystyki poezji Lalicia, która jest gotowa powiedzieć światu „tak”, wbrew okrucieństwu nieba, jego wpływowi na los i wbrew temu, że świat pod koniec drugiego tysiąclecia ugrzązł w złu i negacji ${ }^{3}$.

„Tak”, które poezja (i poeta) mówi światu stanowi nie tyle wyraz buntu czy niezgody na panujący porządek rzeczywistości, co akt sensotwórczy. Przemijanie i śmierć - z którymi Lalić nieustannie zmaga się w swojej poezji ${ }^{4}$ - mają, zdawałoby się, nieodpartą moc odbierania człowiekowi nadziei i wiary w istnienie sensu jego egzystencji, jednak to właśnie poezja może i powinna ten sens odnajdywać i przywracać. W ten sposób staje się ona odpowiedzią na najgłębszą ludzką potrzebę - zrozumienia, że życie, choć skończone, nie jest daremne. O afirmacji świata w poezji Lalicia wypowiedział się także Aleksander Jovanović, w tekście poświęconym interpretacji innego wielkiego symbolu w twórczości Lalicia - późnego lata jako metafory pełni rozwoju stanowiącej jednocześnie początek rozpadu:

W ten sposób Lalić podkreśla w swojej poezji [...] potrzebę, by powiedzieć światu: Tak, wbrew temu, że dostrzega się w nim kruchość i daremność wszelkich ludzkich wysiłków; by przy pomocy poezji wzmacniać potrzebę sensu i nadziei jako ważnych aspektów ludzkiej skończoności ${ }^{5}$ [wyróżnienie kursywą pochodzi od autora].

Powyższe wnioski, jakie badacze wyciągnęli z interpretacji wybranych utworów i kluczowych dla twórczości Lalicia symboli, potwierdził również w jednym z wywiadów sam autor, przywołując myśl Rilkego, dotyczącą roli poezji i zadań poety:

Być może Rilke ma rację, gdy mówi, mając na myśli zadanie poety: „My jesteśmy pszczołami tego, co niewidzialne. W zachwycie zbieramy miód tego, co widzialne, żeby wypełnić nim wielki, złoty ul Niewidzialnego". Dla mnie ta przenośnia stanowi jedynie przykład innego sposobu

${ }^{3}$ S. Šeatović-Dimitrijević, Lalićevo more, od mediteranske čulnosti do starozavetnog straha, [w:] Postsimbolistička poetika..., op. cit., s. 144 (tlumaczenie własne).

${ }^{4} \mathrm{Na}$ temat obecności problemu śmierci w poezji I. V. Lalicia zob. m.in. A. Jovanović, Pesnik zrelog leta, [w:] Ivan V. Lalić. Pesnik, ur. D. Hamović, Kraljevo 1996, s. 97-112.

${ }^{5}$ Ibidem, s. 112 (tłumaczenie własne). 
na to, by powiedzieć, że zadanie poety polega na tym, by - wbrew wszystkiemu co straszne

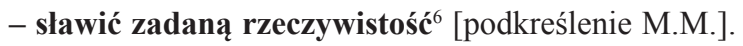

\section{Bizancjum w poezji Ivana V. Lalicia}

Bizancjum jako złożone, „uniwersalne historyczne i kulturowe pojęcie"ך jest jednym z najważniejszych i najczęściej przywoływanych motywów w twórczości poetyckiej Lali$\mathrm{cia}^{8}$. Bezpośrednio - w tytule lub za pomocą jednoznacznych sygnałów intertekstualnych - pojawia się w około piętnastu utworach, a w kilkunastu kolejnych w postaci nawiązań nietematycznych ${ }^{9}$. Odwołanie do Bizancjum jest szczególnie czytelne w grupie dziesięciu wierszy, które noszą tytuł Vizantija (Bizancjum) z kolejnymi cyframi rzymskimi II-X. Siedem z nich znajduje się w omawianym tu cyklu $O$ dziełach miłości albo Bizancjum.

Jak wskazywał sam Lalić, Bizancjum interesowało go na dwóch poziomach: historycznym i mitycznym:

Istnieją mianowicie dwa Bizancja, oba równie ważne dla mojego doświadczenia poetyckiego. Istnieje Bizancjum historyczne, którego znaczenia dla duchowej i intelektualnej kultury mojego narodu nie da się przecenić. Istnieje też mityczne (,Wszyscy mamy swoje Bizancjum, z którego nas wyrzucono, do którego należymy", mówi Charles Simić); Bizancjum to także metafora świadomości pochodzenia, powszedniej ciągłości. W części moich wierszy próbowałem doprowadzić te dwa Bizancja do dialogu między tym co historyczne a tym, co mityczne. Do tego dialogu dochodzi za pośrednictwem obrazów, za pośrednictwem metafor ${ }^{10}$.

Poziom historyczny dotyczy przede wszystkim związku kultury rodzimej (serbskiej) z bizantyńską i, za jej pośrednictwem, z Antykiem jako źródłem kultury europejskiej. O tym aspekcie Bizancjum w twórczości Lalicia pisał m.in. inny poeta, należący do tego samego pokolenia i często z Laliciem porównywany, Jovan Hristić. W przedmowie do tomu Izabrane i nove pesme zauważył on, że odwoływanie się do świata kultury bizantyńskiej to wyraz poszukiwania przez Lalicia „drugiej tradycji” rozumianej w duchu eliotowskim jako tej, która ma określać miejsce twórcy i literatury powstałej w jego języku w szerszym kontekście historyczno-kulturowym. Przywołując ją, poeta wskazuje na ciągłość tradycji uniwersalnej, europejskiej i tradycji narodu, do którego sam przynależy ${ }^{11}$.

${ }^{6}$ I.V. Lalić, Poezija - pohvala čudu zadanog nam sveta (izvodi iz razgovora), [w:] I.V. Lalić, Dela Ivana V. Lalića, priredio A. Jovanović, t. IV: O poeziji, Beograd 1997, s. 290 (tłumaczenie własne).

7 S. Šeatović-Dimitrijević, Tradicija $i$ inovacija. Intertekstualnost u pesništvu Ivana V. Lalića, Beograd 2004, s. 96.

${ }^{8}$ O obecności i znaczeniu motywu Bizancjum w twórczości Lalicia zob.: J. Hristić, Predgovor, [w:] I.V. Lalić, Izabrane i nove pesme, Beograd 1969; Lj. Simović, Smetnje na vezama Ivana V. Lalića, [w:] I.V. Lalić, Smetnje na vezama, Beograd 1975; S. Šeatović-Dimitrijević, Tradicija i inovacija..., op. cit., s. 94-103; B. Jović, Vizantija i vizantinizam kod K. Kavafija, V.B. Jejtsa, I.V. Lalića i R. Silverberga, [w:] Postsimbolistička poetika..., op. cit., s. 250-255.

9 B. Jović, op. cit., s. 252.

10 I.V. Lalić, Poezija - pohvala ..., op. cit., s. 282 (tłumaczenie własne).

11 Zob. J. Hristić, op. cit., s. V-XX. 
Przywołując symbole i motywy skoncentrowane wokół Bizancjum, Lalić dołącza do szeregu autorów, którzy od początku XX wieku poszukiwali źródeł kultury i literatury serbskiej w dziedzictwie wschodniego cesarstwa rzymskiego, sprzeciwiając się zastanym tendencjom do upatrywania jej korzeni wyłącznie w rustykalnej ludowości ${ }^{12}$.

Z kolei poziom mityczny wiąże się u Lalicia ze specyficznym rozumieniem procesu historycznego. Ważne miejsce zajmuje w nim Bizancjum jako symbol rzeczywistości, która osiągnąwszy doskonałość, rozpada się i przestaje istnieć. Pisał o tym między innymi poeta i eseista Ljubomir Simović w przedmowie do tomu poetyckiego Lalicia zatytułowanego Smetnje na vezama. Według niego omawiany twórca:

[...] klęskę Bizancjum, przesunięcie środka ciężkości, pustkę w centrum rozumie jako dialektykę historii. Bizancjum przestaje istnieć w momencie, w którym osiągnęło właściwy sobie, niezbadany cel, gdy wyczerpało swoją siłę, by dalej udoskonalać to, czemu było poświęcone... Klęska Bizancjum nie jest tragiczna, tylko zgodna z logiką... ${ }^{13}$.

W wizji poetyckiej Lalicia rozpad Bizancjum staje się czymś więcej, niż faktycznym wydarzeniem z przeszłości - jego los uznany zostaje za stały mechanizm procesu historycznego, a nawet więcej: za zasadę metafizyczną. Na takie rozumienie wskazywać może strukturalne podobieństwo metafory Bizancjum i innego ważnego symbolu, pojawiającego się często u serbskiego poety, mianowicie późnego lata. Jak dowodził Aleksandar Jovanović, motyw ten, obecny w wielu utworach Lalicia (m.in. Leto, Nikada samlji, Ljubav u julu, Vizantija X, Parkama), dotyczy pory roku, w której natura osiąga pełną dojrzałość, ale w tej pełni zawsze dostrzegalne jest już „pęknięcie”, zapowiedź rozkładu i unicestwienia. W ten sposób, jak twierdził Jovanović, lato staje się dla Lalicia metaforą śmierci i przemijania, które towarzyszą istnieniu we wszystkich jego przejawach, zwłaszcza tych osiągających doskonałość, pełnię rozwoju ${ }^{14}$.

W przypadku Bizancjum proces historyczny nie kończy się jednak na rozpadzie, gdyż ciągłość istnienia cesarstwa podtrzymują narody czerpiące z jego kulturowego dorobku i przenoszące go na grunt własnej tradycji. Tę funkcję pamięci spadkobierców wydobył Bojan Jović. Według niego w utworach Lalicia odwołujących się do motywów bizantyńskich:

[...] Bizancjum pojawia się jako zrealizowany ideał, który musi ponieść karę i doświadczyć klęski, a jego jedyną nadzieją na to, by jakoś przedłużyć swoje istnienie jest pamięć młodych (słowiańskich) ludów, które dopiero wstępują na scenę historii ${ }^{15}$.

Podtrzymywanie istnienia dawnej kultury poprzez kontynuację tradycji i pielęgnowanie pamięci wiąże się ze specyficzną koncepcją czasu, w której przeszłość współistnieje z teraźniejszością i przyszłością. W poezji Lalicia plany czasowe się przeplatają, przeszłość i teraźniejszość wpływają na siebie nawzajem i pozostają w nieustannym dialogu. Wpływ

${ }^{12}$ Do tych autorów należą według Hristicia: Jovan Dučić, Milan Rakić, Milutin Bojić, Vasko Popa, Miodrag Pavlović, Branko Miljković oraz on sam.

${ }^{13} \mathrm{Lj}$. Simović, ,Smetnje na vezama” u knjizi Ivana V. Lalića „Smetnje na vezama”, Beograd 1975, s. 113-114, za: S. Šeatović-Dimitrijević, Tradicija i inovacija ..., op. cit., s. 95 (tłumaczenie własne).

14 Por. A. Jovanović, Pesnik zrelog leta..., op. cit., s. 97-112.

15 B. Jović, op. cit., s. 253-254 (tłumaczenie własne). 
przeszłości na współczesnych i ich kluczową rolę dla ocalenia przeszłości uosabia w wierszach z cyklu $O$ dziełach miłości albo Bizancjum podmiot mówiący. Autor wewnętrzny ${ }^{16}$ utworów występuje z perspektywy teraźniejszości - ma bowiem wiedzę o tym, jaki los spotkał Bizancjum - ale jednocześnie przybiera maskę kogoś, kto z tymi przeszłymi wydarzeniami współistnieje, dla kogo dzieją się one w momencie ich relacjonowania. Podmiot utworów poświęconych tematyce bizantyńskiej w omawianym cyklu może być zbiorowy (jak w pierwszym i ostatnim wierszu: Plač letopisca i Vizantija VII) lub indywidualny, jednak niezależnie od formy, jego głos pozostaje łącznikiem między teraźniejszością a przeszłością.

\section{Bizancjum a dzieła miłości}

W utworze otwierającym cykl $O$ dziełach miłości albo Bizancjum, zatytułowanym Plač letopisca (Płacz kronikarza), podmiot liryczny, tytułowy kronikarz, już od początku utworu jasno wskazuje na sytuację, w jakiej znalazł się on i jemu współcześni:

Dzieła nasze obrzeżone są próżnią,

Wyspy o kruchych krawędziach rozsiane po morzu:

Ile ciszy na każde wątłe słowo,

Ile nieba na każdy pion kolumny,

Ile straszliwej harmonii ma w sobie ruina! [123 $]^{17}$.

W tych początkowych wersach pojawia się rzeczywistość towarzysząca motywowi Bizancjum w całym omawianym cyklu: pustka, śmierć, rozpad, dezintegracja, które odbierają sens ludzkiej działalności, niszcząc jej kruche wytwory. Lament kronikarza zawiera jednocześnie pytanie, czy to, co zostało rozpoczęte w Bizancjum, będzie kontynuowane i czy zdezintegrowane części zostaną na powrót scalone:

Kto ma dokończyć rękopis, księgę, którą próżnia

Kartkuje palcami z płomienia? [124] ${ }^{18}$.

Skierowane w przyszłość, nasycone rezygnacją pytanie „kto?” odnosi się do większości utworów cyklu, w których oprócz Bizancjum jako temat pojawia się także serbska kultura narodowa (w wierszach Raška czy Catena Mundi). Wydaje się jednak, że pytanie to niesie z sobą coś więcej niż kwestię kontynuacji tradycji przez spadkobierców antycznej kultury. Perspektywa tego, czym są wspomniane „dzieła"/"uczynki" ${ }^{19}$, zagrożone przemijaniem,

\footnotetext{
${ }^{16}$ Kategorię ,autora wewnętrznego” przejęłam od Edwarda Balcerzana, Zob: E. Balcerzan, Styl i poetyka twórczości dwujęzycznej Brunona Jasieńskiego, Wrocław 1968, s. 19-26.

17 „Dela su naša omeđena prazninom, / Lomnih ivica, ostrva rasejana po moru; / Koliko tišine na svaku nejaku reč, / Koliko neba na svaki osovljeni stub, / Koliko strašnog sklada ima u ruševini!” [153]. Wszystkie cytaty z oryginalnych utworów na podstawie wydania: I.V. Lalić, Dela Ivana V. Lalića, t. II, op. cit. Wszystkie tłumaczenia wierszy na język polski, o ile nie zaznaczono inaczej, na podstawie wydania: I.V. Lalić, $O$ dziełach mitości..., op. cit. Numery stron podano w nawiasach kwadratowych obok cytatu.

18 „Ko da dovrši rukopis, knjigu koju praznina / Prelista prstima od plamena?” [153].

19 Serbskie słowo „delo” można tłumaczyć na dwa sposoby, jako „dzieło” lub „,czyn, uczynek”.
} 
pustką i brakiem sensu, poszerza się w wierszu $O$ delima ljubavi ( $O$ dziełach miłości), w którym czytamy:

Dzieła miłości rozsiane są po świecie

Jak ślady bitew:

a trawa wyrasta

Na pobojowisku

mokry płomień ziemi $[127]^{20}$.

O ile w wierszu Płacz kronikarza, podmiot mówiący, który wciela się w twórcę jednego z gatunków dziejopisarstwa literackiego, może wskazywać, że „dzieła”/"uczynki” obejmują głównie kulturowe wytwory działalności człowieka, o tyle w przywołanym tu utworze rozpad i dezintegracja odnosi się do dużo szerszej kategorii - do „dzieł miłości”. Aby zrozumieć, czym one są, należy bliżej przyjrzeć się różnym aspektom motywu miłości, które pojawiają się w badanym cyklu poetyckim.

A. Miłość jako broń lub narzędzie. W utworze Veče na bedemu (Wieczór na szańcu), drugim wierszu cyklu, podobnie jak w pierwszym budowana jest atmosfera rezygnacji, pustki i oczekiwania na zagrożenie:

Pusta jest łąka pośrodku morza,

Kwiaty zdziczały, opustoszały ule,

Samorodny granat dojrzewa,

czerwona strawa umarłych $[\ldots]$

I cyklopowe oko bestii patrzy na nas

Przez otwarte wrota ${ }^{21}$.

Pojawia się w nim jednak również przeciwwaga w postaci światłości padającej z góry na zbiorowy podmiot mówiący:

Spójrz, światłość pada

Na nasze głowy, na ramiona,

Miesza się z naszym pocałunkiem przy rozstaniu

Jak smak morza $\mathrm{z}$ obrzędowym winem -

broń nasza, nieme narzędzie miłości $[\ldots]^{22}$.

Występującą w tym kontekście miłość można interpretować, ze względu na jej otoczenie semantyczne - ,światłość”, „obrzęd”, „,broń”, „narzędzie” - jako przeciwwagę dla zagrażającego bezsensu, oręż, który podmiot mówiący „ma w ręku”, co sprawia, że nie jest

20 „Dela su ljubavi po svetu razasuta / Kao tragovi bitke; / a trava buja / Na razbojištu, mokri plamen zemlje [...]" [159] (thumaczenie własne).

21 „Pusta je livada vatre nasred mora, / Cveće podivljalo i prazne košnice, / Zri samonikli nar, / crvena hrana mrtvih [...] // I kiklopsko oko zveri motri nas / Kroz otškrinute dveri” [154].

${ }^{22}$ „Gle, silazi svetlost / Na glave naše, na ramena, / U poljubac nam se meša na rastanku / Kao more u ukus vina obrednog // oružje naše, nemušte sprave ljubavi [...]" [154] (tłumaczenie własne). 
bezradny wobec wszechogarniającej pustki. W podobnym kontekście miłość pojawia się także w utworze Raška:

Chyba jednak prawdziwy jest znak, wysunięty

Pośród tego zgiełku, gdzie oręż miłości

Wykuwa się w mroku jak potomstwo ${ }^{23}$

oraz w utworze Vavilonski zidari (Murarze babilońscy), w którym do głosu dochodzą budowniczy wieży Babel. Wspominają oni czasy sprzed boskiej interwencji, gdy wspólnymi siłami budowali wieżę, która jest $\mathrm{w}$ tym utworze przedstawiana jako metafora śmiałego przedsięwzięcia ludzkości, tworzonego wbrew możliwym negatywnym konsekwencjom:

Czy i co śpiewaliśmy na rusztowaniu,

Gdy wieża była miarą ponad możliwe nieszczęście

I wzniesiony kamień miarą wszystkich miar, kielnia

Narzędziem miłości we wzruszonym powietrzu ${ }^{24}$.

Miłość, której narzędzie stanowią instrumenty używane przez budowniczych wieży Babel, może być rozumiana jako rodzaj energii inspirującej człowieka do niemożliwego wysiłku „wbrew wszystkiemu, co straszne”, pozwalającej wznieść się ponad „możliwe nieszczęście". Krótko mówiąc, w wymienionych utworach miłość jest rozumiana jako narzędzie obrony przed brakiem sensu oraz jako sprzymierzeniec w przedsięwzięciach, które mogą prowadzić do tragicznego konfliktu z Bogiem, nadają jednak człowiekowi niezbywalną godność.

B. Miłość między istnieniem a nieistnieniem. W nieco innym kontekście motyw miłości pojawia się w wierszu Sećanje na voćnjak (Wspomnienie o sadzie). W utworze tym jako kontekst wykorzystany jest mit o nimfie Melisie, który w twórczości Lalicia stanowi metaforę relacji między istnieniem a nieistnieniem ${ }^{25}$. Przestrzeń utworu, sad późnym latem, mieści w sobie dwa światy, rzeczywisty, w którym:

[...] sad był już obrany,

Dojrzewały tylko owoce rzadkie i późne

W ciemnym trzepoczącym listowiu o schnących rąbkach $[129]^{26}$.

${ }^{23}$ „Biće da je ipak tačan znak, isturen / U središtu ovog meteža, gde se oružje ljubavi / Kuje u mraku, kao pomostvo" [177] (tłumaczenie własne).

${ }^{24}$ „Da li smo, šta li smo pevali na skelama / Kad kula beše mera iznad moguće nesreće / I kamen podignut mera / mere, mistrija / Oruđe ljubavi u vazduhu uzbuđenom [...] [169]" (thumaczenie własne).

25 Wokół postaci Melisy, mitycznej nimfy, której ciało zostało zamienione w rój pszczół, Lalić stworzył cykl poetycki Melisa (1959), nawiązuje do niego także w cyklu Deset soneta nerođenoj kćeri (1992). Melisa stanowi w tych utworach symbol nierozerwalnego związku tego co widzialne z dziedziną niewidzialnego, co można rozumieć też jako relację między istnieniem a nieistnieniem. Na ten temat pisałam w artykule poświęconym drugiemu ze wspomnianych cykli (por. M. Maszkiewicz, Hermeneutyka i teoria intertekstualności jako metodologia badań modernizmu w poezji serbskiej drugiej połowy XX w. na przykładzie cyklu Deset soneta nerođenoj kćeri Ivana V. Lalicia, „Adeptus”, 2015, nr 6, s. 1-10).

${ }^{26}$, ,...] voćnjak je bio obran, / Dozrevali su samo plodovi retki i pozni / U tamnom treptavom lišću sa suvim ivicama [...]" [160]. 
oraz nierzeczywisty:

Odchodząc stąpałaś zaledwie o krok przede mną

Przez ogród nagle pełny wszystkich owoców ziemi

Przez nikogo niezbieranych,

o nieznanym smaku $[130]^{27}$.

W zbudowanej w tej sposób przestrzeni, której dychotomiczność jest jeszcze wzmocniona jednoczesną przynależnością Melisy do różnych porządków czasowych, teraźniejszości i przeszłości:

Nieświadoma, że powtarzasz, że jesteś odbiciem

Siostrzanych ust strawionych przez morze

W pewnym zamierzchłym jabłonnym sadzie piany $[131]^{28}$,

padają słowa, dotyczące uczucia miłości:

Może wtedy powiedziałaś:

„Jednak zdaje mi się, że najpiękniejsze jest

To, co kochamy z przeczuciem w duszy" $[\ldots][131]^{29}$.

Miłość wypełniona „,przeczuciem” odnosi się, jak można przypuszczać, do dziedziny tego, co nierzeczywiste, niedającej się zbadać i poznać inaczej niż za pośrednictwem „odbicia" pozostawianego w tym, co rzeczywiste. W utworze Wspomnienie o sadzie dochodzi do włączenia motywu miłości w dychotomię istnienia i nieistnienia, która jest stałym elementem twórczości Lalicia. Nawiązanie do świata pozostającego poza tym, co istnieje, stanowi kontekst miłości również w innym wierszu cyklu, zatytułowanym Zavičaj (Ojczy$z n a$ ). Miłość jest w nim wspomniana dwukrotnie jako atrybut „drugiej strony”, która w poezji Lalicia stanowi zwykle korelat tego, co nieistniejące lub (w innej wersji wspomnianej opozycji) niewidzialne:

Z sercem ściśniętym jak szyjka klepsydry

Układałem ojczyznę, cząstka po cząstce,

Ze znaków dopełniających mnie jak sprawiedliwość

Po drugiej stronie, gdzie powód miłości jest nieważny

A miłość powszednia [...] [140] $]^{30}$.

C. Miłość nadająca sens. Melisa jest adresatką jeszcze jednego utworu z cyklu $O$ dziełach miłości albo Bizancjum, zatytułowanego Tri strofe (Trzy strofy). Wiersz ten wprowa-

${ }^{27}$ „Na odlasku si išla tek korak ispred mene / Kroz voćnjak naglo težak od svih plodova zemnih / Koje ne bere niko, / čiji je ukus neznan" [160].

${ }^{28}$ „Nesvesna da se ponavljaš, ogledalo da si / Sestrinskih usta koje je razjelo more / U davnom jednom jabučaru pene" [161].

${ }^{29}$ „Možda si tada rekla: / «ipak mislim da najlepše je / Ono što volimo sa slutnjom u duši»” [...] [161] .

${ }^{30}$ „Srca stegnuta kao grlo peščanog sata / Sastavljao sam zavičaj, / deo po deo, / Od znakova koji me sustižu kao pravda / Sa druge strane, gde je povod ljubavi nevažan / A ljubav nasušna [...]" [175]. 
dza kolejny aspekt motywu miłości, który wiąże się z nadawaniem sensu (,usprawiedliwianiem”, „uniewinnianiem”) rzeczywistości:

Po wszystkim miłość nas uniewinni:

Jeśli ogień swym wapiennym ściegiem

Kruchy kamień wieków, próchno, litery

Złączy w słowa $[\ldots][133]^{31}$.

W przytoczonym fragmencie miłość i ogień przynależą do tego samego porządku, są czynnikami scalającymi rozbite fragmenty przeszłości (,Vatra [...] ako spoji / Lomni kamen vekova”), nadającymi jej sens. Miłość występuje zatem w opozycji do przemijania i rozpadu.

Motyw miłości w funkcji integrującej i sensotwórczej rozwijany jest także w wierszu zamykającym cykl $O$ dziełach miłości albo Bizancjum, zatytułowanym Vizantija VII. Utwór ten stanowi kompozycyjne domknięcie cyklu, odpowiedź na powracające pytanie o przyszłość, które zadają sobie Bizantyńczycy: kto przyjdzie po nich i czy będzie kontynuował ich dzieło. Odpowiedź na nie udzielona jest nie w formie pewnika, lecz refleksji:

Być może ktoś, z mądrą świtą naszych dusz

Przechadzać się będzie kiedyś po linii tych szańców, z których my

Oglądaliśmy słońce $[\ldots][145]^{32}$.

W utworze tym dochodzi do znamiennego nałożenia się na siebie kilku płaszczyzn czasowych. Podmiot mówiący zbiorowy, złożony z głosów pochodzących z Bizancjum, snuje przypuszczenia na temat swojej przyszłości, czyli teraźniejszości - jeśli spojrzeć z perspektywy autora wewnętrznego i odbiorców wiersza; jednak to właśnie autor wewnętrzny jest tym, który za pośrednictwem poezji w swojej teraźniejszości na powrót ożywia Bizancjum, przywołując związaną z nim symbolikę i tworząc dla niej nowy kontekst. Zatem mimo iż wypowiedź podmiotu mówiącego w tym utworze przenika (modernistyczna) niepewność, to jednocześnie sama ta wypowiedź stanowi nadanie Bizancjum przez autora wewnętrznego, reprezentanta następców, nowego sensu.

W przyszłości, jaką podmiot liryczny projektuje w tym wierszu, dochodzi zarazem do ponownego scalenia dzięki aktowi mowy „dzieł/uczynków miłości”, które zostały, jak pamiętamy, ,rozrzucone po świecie”:

\section{[...] powietrze będzie błękitne}

Od dymu naszych imion; ale kto nas zrozumie?

Bowiem przemieszczony będzie środek, obrazy będą inne,

[...] a dzieła miłości w mowę wtopione, w język [...] [145]

31 „Posle svega ljubav će da nas pravda; / Vatra krečnim vezivom ako spoji / Lomni kamen vekova, trulež, slova / Složi u reči [...]" [162].

32 „Neko će možda, u mudroj pratnji naših duša / Šetati jednom po crti ovih bedema, gde smo / Gledali sunce $[\ldots]^{\prime \prime}[184]$.

${ }^{33}$, ,...] vazduh će biti modar / Od dima naših imena; / no ko će da nas razume? / Jer pomereno biće središte, slike drukčije, / [...] A dela ljubavi u govor spojena, u jezik [...]" [184]. 
Odbywa się to jednak kosztem Bizancjum, które nie będzie już mogło być zrozumiane - podtrzymanie jego istnienia będzie możliwe tylko o tyle, o ile zostanie ono włączone w rzeczywistość ,innych obrazów”, czyli do nowej całości symbolizowanej tu przez mowę. „Dzieła/uczynki miłości” uzyskają nowy sens, jest to jednak sens widziany z perspektywy przyszłości, widoczny dla następców, niedostępny podmiotowi lirycznemu w jego tu i teraz.

\section{O dziełach/uczynkach miłości}

Wszystkie wymienione funkcjonalizacje motywu miłości w cyklu $O$ dziełach miłości albo Bizancjum (miłość jako broń lub narzędzie, miłość przekraczająca opozycję między istnieniem a nieistnieniem, miłość nadająca nowy sens scalonym ponownie elementom) pojawiają się w wierszu $O$ delima ljubavi ( $O$ dziełach miłości). Z dotychczasowych prób omówienia $\mathrm{i}$ interpretacji motywu miłości wynika, iż „dzieła” te mogłyby być rozumiane jako wszelkie działania człowieka, w których dąży on do dostrzeżenia lub nadania sensu, bez względu na trudności wywoływane przez niepojęty, pełen sprzeczności świat, gdzie każdy wytwór ludzki prędzej czy później przemija, a osiągnięcie doskonałości wiąże się nieodłącznie z postępującym rozkładem:

I kiedy kruszeje ściana, i kiedy ogród dziczeje,

I kiedy ściera się słowo, i kiedy pęka pierścień,

Miłość ponosi straty [...] [127] $]^{34}$.

W zakończeniu utworu miłość zostaje jednak przedstawiona w nieoczekiwanej perspektywie, jako siła, która jest potężniejsza od rządzącego światem przemijania:

[...] ale posłuchaj krzyków ptasich

Nad zatoką, gdzie morze od kochanków się uczy

Innej czułości: czas jest beznamiętny,

a świat jest miłości zadany,

długie ćwiczenie

Dla niedojrzałych bogów $[128]^{35}$.

Morze, symbolizujące wcześniej zagrożenie, w obliczu którego stanęło Bizancjum, czyli pustkę i rozkład, okazuje się być „uczniem kochanków”. Dzieła ludzkiej miłości stanowią zatem nową, ważną jakość w strukturze rzeczywistości. Świat, z pozoru przynoszący jedynie brak nadziei i pozbawiony sensu, zostaje uznany za ćwiczenie - coś, co ludzie muszą wykonywać, by się doskonalić. W obliczu śmierci i przemijania sensowność ich wysiłków nie tylko nie zostaje przekreślona, ale wręcz zyskuje nową możliwość potwierdzenia swojej ważności.

${ }^{34}$ „I kad se mrvi zid, i kada vrt podivlja, / Kad istare se slovo, kad razbije se prsten, / Ljubav je na gubitku $[\ldots]^{\prime \prime}[159]$.

35, ,...] no slušaj krikove ptica / Nad uvalom gde more od ljubavnika uči / Drukčiju nežnost: vreme je / nepristrasno, / A svet je ljubavi zadan, / duga vežba / Bogova nedoraslih” [159]. 
Wracając do koncepcji, według której zadaniem poezji jest mówienie światu „tak”, można zauważyć, że miłość - w sensie, jaki wyłania się z cyklu $O$ dziełach miłości albo Bizancjum - stanowić może esencję postulowanej przez Lalicia afirmacji rzeczywistości. Struktura symboliczna, na którą składa się z jednej strony Bizancjum jako byt doskonały i przez to skazany na unicestwienie, stający w obliczu pustki i utraty sensu, z drugiej zaś miłość jako działalność sensotwórcza, stanowią całościową koncepcję, na której opiera się wizja świata w poezji Lalicia. Poeta stale rozważa problemy śmierci i przemijania, będące nieodłączną częścią świata, nieustannie porusza się na granicy między tym, co istnieje a tym, co (już) nie istnieje. Jednocześnie zaś potrafi znaleźć i wskazać - „wbrew wszystkiemu co straszne" - możliwe sposoby afirmacji rzeczywistości, choć przeważnie nie czyni tego za pomocą zdecydowanych twierdzeń, lecz w formie pytań i przypuszczeń, w sposób ostrożny i wyważony, nie pozbawiony powątpiewania i sceptycyzmu.

\section{Bibliografia}

Balcerzan E., Styl i poetyka twórczości dwujęzycznej Brunona Jasieńskiego, Wrocław 1968.

Delić J., Lalićev dijalog sa savremenom srpskom poezijom - ka eksplicitnoj poetici Ivana V. Lalića,

[w:] Postsimbolistička poetika Ivana V. Lalića. Zbornik radova, ur. A. Jovanović, Beograd 2007.

Hristić J., Predgovor, [w:] I.V. Lalić, Izabrane i nove pesme, Beograd 1969.

Jovanović A., Pesnik zrelog leta, [w:] Ivan V. Lalić. Pesnik, ur. D. Hamović, Kraljevo 1996.

Jovanović A., Poezija srpskog neosimbolizma, Beograd 1994.

Jović B., Vizantija i vizantinizam kod K. Kavafija, V.B. Jejtsa, I.V. Lalića i R. Silverberga, [w:] Postsimbolistička poetika Ivana V. Lalića. Zbornik radova, ur. A. Jovanović, Beograd 2007.

Lalić I.V., Dela Ivana V. Lalića, prir. A. Jovanović, t. II: O delima ljubavi ili Vizantija, Beograd 1997.

Lalić I.V., O dziełach miłości albo Bizancjum, wybór, przekład i posłowie J. Salamon, Kraków 1977.

Lalić I.V., Poezija - pohvala čudu zadanog nam sveta (izvodi iz razgovora), [w:] I.V. Lalić, Dela Ivana V. Lalića, prir. A. Jovanović, t. IV: O poeziji, Beograd 1997.

Maszkiewicz M., Hermeneutyka i teoria intertekstualności jako metodologia badań modernizmu w poezji serbskiej drugiej połowy XX w. na przykładzie cyklu Deset soneta nerođenoj kćeri Ivana V. Lalicia, „Adeptus” 2015, nr 6, s. 1-10;

Postsimbolistička poetika Ivana V. Lalića. Zbornik radova, ur. Jovanović A., Beograd 2007.

Šeatović-Dimitrijević S., Lalićevo more, od mediteranske čulnosti do starozavetnog straha, [w:] Postsimbolistička poetika Ivana V. Lalića. Zbornik radova, ur. A. Jovanović, Beograd 2007.

Šeatović-Dimitrijević S., Tradicija i inovacija. Intertekstualnost u pesništvu Ivana V. Lalića, Beograd 2004.

Simović Lj., Smetnje na vezama Ivana V. Lalića, [w:] I.V. Lalić, Smetnje na vezama, Beograd 1975. 


\title{
Byzantium as an ideal doomed to annihilation and loves that gives meaning in the poetic series Of the Works of Love, or Byzantium by Ivan V. Lalić
}

\begin{abstract}
Summary
The goal of this article is to interpret the two motifs indicated in the title which intertwine in the poetic series Of the Works of Love, or Byzantium by Ivan V. Lalić, a Serbian poet. Perception of Byzantium as a reality which, having reached perfection, is annihilated and of love as a meaning-giving category connects with a coherent vision in the author's entire work. The reflections presented in this article provide an impetus to comprehend the series in question, and Lalić's entire poetry.
\end{abstract}

Keywords: Serbian poetry, Ivan V. Lalić, Byzantium, loves that gives meaning 